\title{
Using Bacillus amyloliquefaciens for remediation of aquaculture water
}

\author{
Fengxing $\mathrm{Xie}^{2^{*}}$, Taicheng Zhu ${ }^{3}$, Fengfeng Zhang ${ }^{2}$, Ke Zhou ${ }^{2}$, Yujie Zhao ${ }^{2}$ and Zhenghua $\mathrm{Li}^{i^{*}}$
}

\begin{abstract}
Remediation of aquaculture water using microorganisms like Bacillus species is a burgeoning trend for the sustainable development of aquaculture industries. In this work, a Bacillus amyloliquefaciens strain (namely B. amyloliquefaciens HN), isolated from activated sludge of a polluted river, was evaluated for its potential in water remediation using simulated aquaculture water. B. amyloliquefaciens $\mathrm{HN}$ exhibited high tolerance towards $80 \mathrm{mg} \mathrm{I}^{-1}$ of nitrite- $\mathrm{N}$ and ammonia-N. It could effectively remove $20 \mathrm{mg} \mathrm{l}^{-1}$ of nitrite- $\mathrm{N}$, but was inefficient in eliminating ammonia-N when the ammonia- $\mathrm{N}$ concentration was below $20 \mathrm{mg} \mathrm{I}^{-1}$. Further studies showed that the ammonia- $\mathrm{N}$ removal by $B$. amyloliquefaciens $\mathrm{HN}$ was more efficient at $30^{\circ} \mathrm{C}$ and $35^{\circ} \mathrm{C}$ than $25^{\circ} \mathrm{C}$, and that maximum nitrite- $\mathrm{N}$ removal rate was achieved at $\mathrm{pH} 8$.
\end{abstract}

Keywords: Bacillus amyloliquefaciens, Aquaculture water remediation, Nitrogenous compound, Nitrite removal

\section{Introduction}

The rapid expansion of intensive aquaculture industries, are often companied by rotted uneaten feed, sedimentation of feces and organic residues. The water quality rapidly deteriorates as a result. In particular, nitrogenous compounds such as ammonia and nitrite quickly build up, which are both harmful to fish and shrimp even at low concentrations (Crab et al. 2007; Mohapatra et al. 2012). Water exchange can be applied to maintain good water quality. However, frequent water exchange is not only laborious and costly, but also may incur disease causing agents and pollute nearby rivers and coastal areas (Mohapatra et al. 2012). Therefore, there is an urgent demand for cost-effective and environment-friendly approaches for remediation of aquaculture water.

In recent years, the use of microorganisms to improve water quality becomes a burgeoning trend (Ninawe and Selvin 2009; Verschuere et al. 2000). Bacillus species are widely used for water remediation because they are stable for long period due to spore formation, easily prepared by

\footnotetext{
* Correspondence: fengxing_xie@126.com; li_zh@tib.cas.cn

${ }^{2}$ Tianjin Research Center of Agricultural Biotechnology, Tianjin 300192,

People's Republic of China

${ }^{1}$ Tianjin Institute of Industrial Biotechnology, Chinese Academy of Sciences, 32XiQiDao, Tianjin Airport Economic Park, Tianjin 300308, People's Republic of China

Full list of author information is available at the end of the article
}

fermentation and possess antagonistic effects on pathogens (Hong et al. 2005). Strains belonging to several Bacillus species, such as Bacillus subtilis, Bacillus cereus, Bacillus licheniformis, Bacillus pumilus were isolated and evaluated for their potential as biological agents for water quality enhancement. Several strains with good nitrogen removal properties were thus found. To date, screening strains with good remediation characteristics still remains a fundamental step towards developing commercial microbial agents.

Previously, we isolated a Bacillus amyloliquefaciens strain, named as B. amyloliquefaciens $\mathrm{HN}$ from the activated sludge of a polluted river. This strain was shown to effectively remove nitrogenous compounds and grow in broad temperature, $\mathrm{pH}$, and salts concentration in preliminary studies. Moreover, no previous studied has characterized the nitrogen removal ability of $B$. amyloliquefaciens. Therefore, the aim of this study is to evaluate $B$. amyloliquefaciens $\mathrm{HN}$ for its remediation properties using simulated aquaculture water.

\section{Materials and methods}

Strains and culture media

B. amyloliquefaciens $\mathrm{HN}$ was isolated from a polluted pool in Xiqing District, Tianjin. The strain was identified by Agricultural Culture Collection of China, and deposited at China General Microbiological Culture Collection Center (CGMCC No. 3261). 

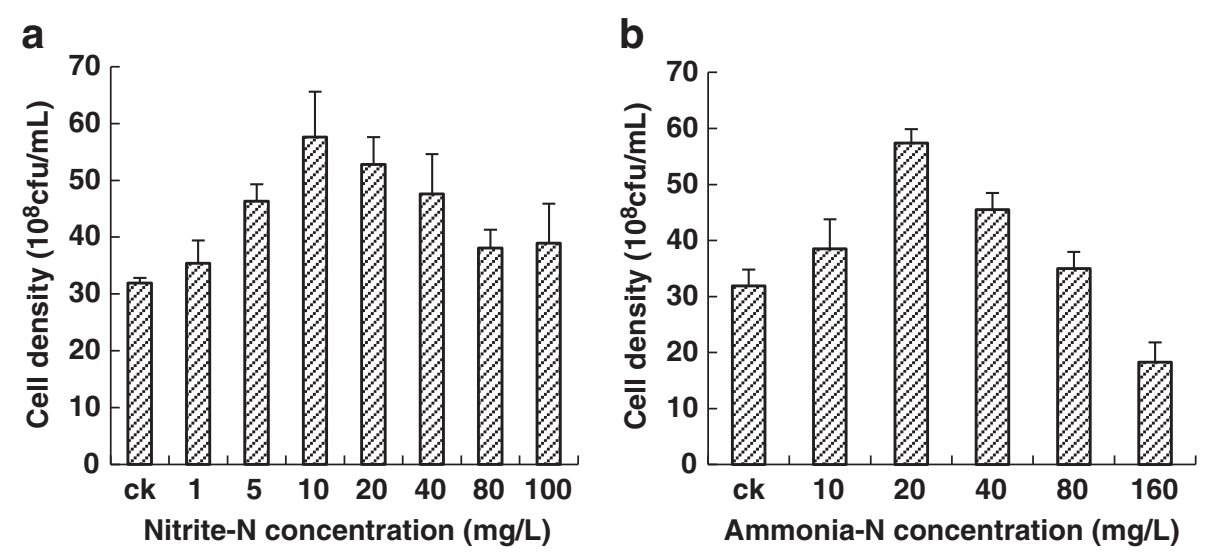

Figure 1 Nitrite and ammonia-N tolerance tests for B. amyloliquefaciens HN. a) Nitrite tolerance tests; $\mathbf{b}$ ) Ammonia-N tolerance tests.

The culture medium (also referred as basal medium) for B. amyloliquefaciens $\mathrm{HN}$ contained (per liter): peptone $8 \mathrm{~g}$, beef extract $3 \mathrm{~g}$, soluble starch $5 \mathrm{~g}, \mathrm{NaCl} 5 \mathrm{~g}$ (plus agar $15 \mathrm{~g}$ for solid medium). The simulated aquaculture water was prepared referring to Chen (2005) and LuzE. DeBashanet (2002), which contained (per liter): beef extract $0.5 \mathrm{~g}$, sucrose $0.5 \mathrm{~g}, \mathrm{NaCl} 0.25 \mathrm{~g}, \mathrm{KH}_{2} \mathrm{PO}_{4} 0.075 \mathrm{~g}$.

\section{Nitrite and ammonia- $\mathrm{N}$ tolerance tests}

Sodium nitrite and ammonium sulfate were added to the culture medium to make the final concentrations of

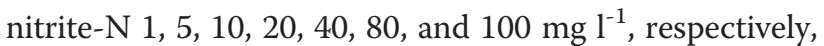
and those of ammonia- $\mathrm{N} \mathrm{10,20,40,80,} \mathrm{and} 160 \mathrm{mg} \mathrm{l}^{-1}$, respectively. All the experiments were repeated thrice with the basal medium as control. Three milliliters of strain culture were inoculated into $250 \mathrm{ml}$ shake flask with $100 \mathrm{ml}$ culture media and cultured at $37^{\circ} \mathrm{C}$.

\section{Removal tests of nitrite- $\mathrm{N}$ and ammonia- $\mathrm{N}$}

The simulated polluted water was prepared by making the final concentrations of nitrite-N 10, 20, 40, and $80 \mathrm{mg} \mathrm{l}^{-1}$,

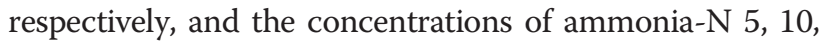
20, and $40 \mathrm{mg} \mathrm{l}^{-1}$, respectively. Three milliliters of strain culture were inoculated into $250 \mathrm{ml}$ shake flask with $100 \mathrm{ml}$ culture media and cultured at $37^{\circ} \mathrm{C}$.

\section{Effects of different conditions on the removal of nitrite-N} and ammonia-N

The model polluted water was prepared to make the initial concentration of nitrite-N was $10 \mathrm{mg} \mathrm{l}^{-1}$, and ammonia-N was $20 \mathrm{mg} \mathrm{l}^{-1}$. The inoculum volume was $3 \%$, and cultured at different temperature $\left(25^{\circ} \mathrm{C}, 30^{\circ} \mathrm{C}\right.$, and $\left.35^{\circ} \mathrm{C}\right)$, and different initial $\mathrm{pH}(\mathrm{pH} 5.0,6.0,7.0,8.0$, and 9.0, adjusted by $\mathrm{NaOH}$ and $\mathrm{HCl}$ ).
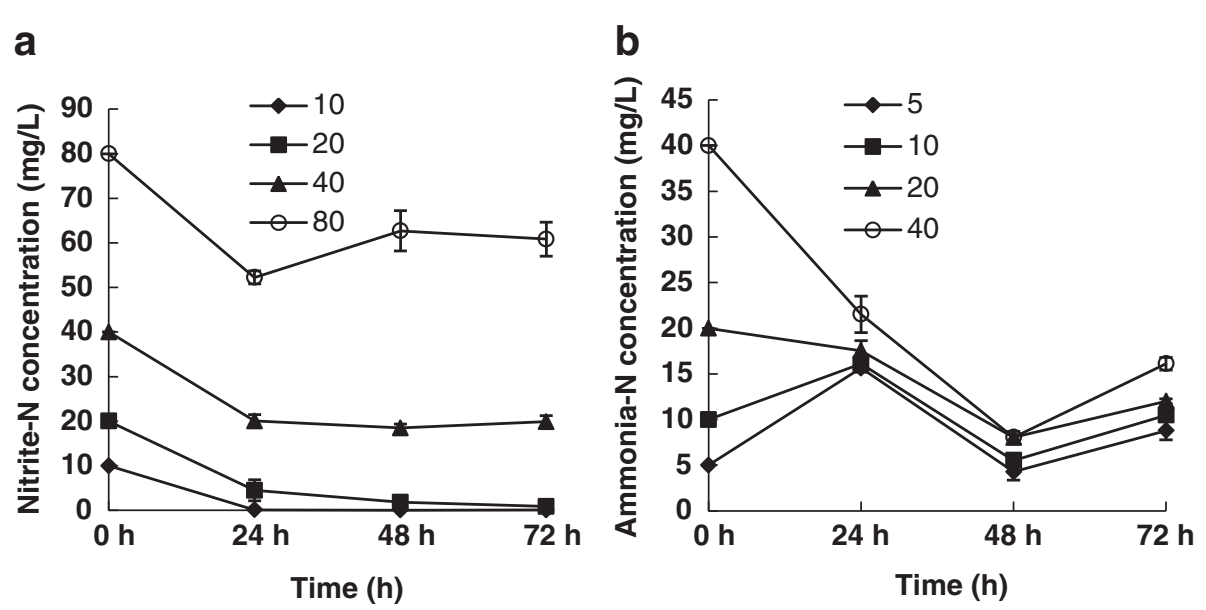

Figure 2 Nitrite and ammonia-N removal tests for $\boldsymbol{B}$. amyloliquefaciens $\mathbf{H N}$. a) Nitrite removal tests; b) Ammonia-N removal tests. 

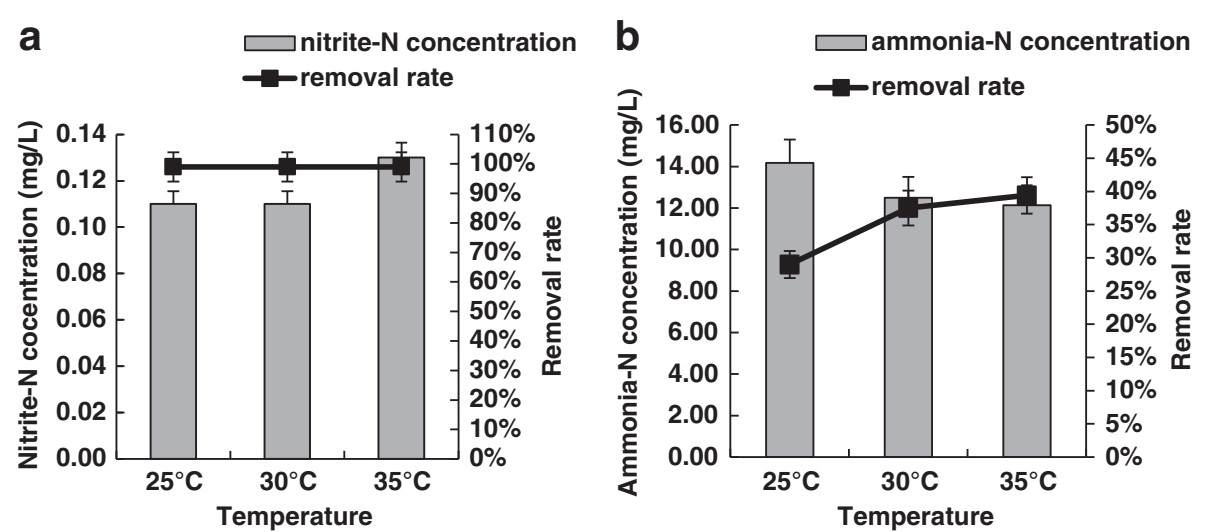

Figure 3 Effects of different temperature on the removal rates of nitrite-N and ammonia-N by B. amyloliquefaciens HN. a) Effects of temperature on nitrite- $\mathrm{N}$ removal rate; $\mathbf{b})$ Effects of temperature on the ammonia- $\mathrm{N}$ removal rate.

\section{Analysis methods}

The Nesslar method was used for ammonia determination. The 1,2-ethanediamine, N-1-naphthalenyl-,dihydrochloride spectrophotometric method was used for the nitrite measurement (APHA, 2005). The nitrate concentration was measured using the salicylic (2-hydroxybenzoic) acid method (Cataldo et al. 1975). Cell concentration was determined by plate counting.

\section{Results}

Nitrite and ammonia- $\mathrm{N}$ tolerance tests for of $B$. amyloliquefaciens $\mathrm{HN}$

For Nitrite-N tolerance test (Figure 1a), cell concentrations of $B$. amyloliquefaciens HN with all tested nitrite$\mathrm{N}$ concentrations were higher that of control, illustrating that the strain could tolerate wide range of nitrite-N. The results also showed that the presence of nitrite- $\mathrm{N}$ could promote the growth of $B$. amyloliquefaciens, especially at low concentrations $(<10 \mathrm{mg} / \mathrm{L})$. The highest cell concentration was achieved with the nitrite-N concentration of $10 \mathrm{mg} \mathrm{l}^{-1}$, which is $80.1 \%$ higher than that of control.

For ammonia-N tolerance test (Figure 1b), all cell concentrations with tested ammonia-N concentrations were higher than that of control, except the one with $160 \mathrm{mg} \mathrm{l}^{-1}$ ammonia-N. The ammonia-N concentration of $20 \mathrm{mg} \mathrm{l}^{-1}$ resulted in the highest cell growth, $79.9 \%$ higher than that of control. The results indicated that $B$. amyloliquefaciens $\mathrm{HN}$ can tolerate ammonia-N ranging from $10 \mathrm{mg} \mathrm{l}^{-1}$ to $80 \mathrm{mg} \mathrm{l}^{-1}$. An ammonia-N concentration of $160 \mathrm{mg} \mathrm{l}^{-1}$ was shown to inhibit the growth of the strain.

\section{Nitrite-N and ammonia- $\mathrm{N}$ removal tests for $B$. amyloliquefaciens $\mathrm{HN}$}

Figure 2a showed that the nitrite- $\mathrm{N}$ could not be detected within $24 \mathrm{~h}$ with an initial nitrite- $\mathrm{N}$ concentration of $10 \mathrm{mg} \mathrm{l}^{-1}$. $90 \%$ of the nitrite- $\mathrm{N}$ was removed in $24 \mathrm{~h}$ for $20 \mathrm{mg} \mathrm{l}^{-1}$, and almost $100 \%$ was removed in $48 \mathrm{~h}$. $19.2 \mathrm{mg} \mathrm{l}^{-1}$ and $20.1 \mathrm{mg} \mathrm{l}^{-1}$ of nitrite- $\mathrm{N}$ (representing $53.8 \%$
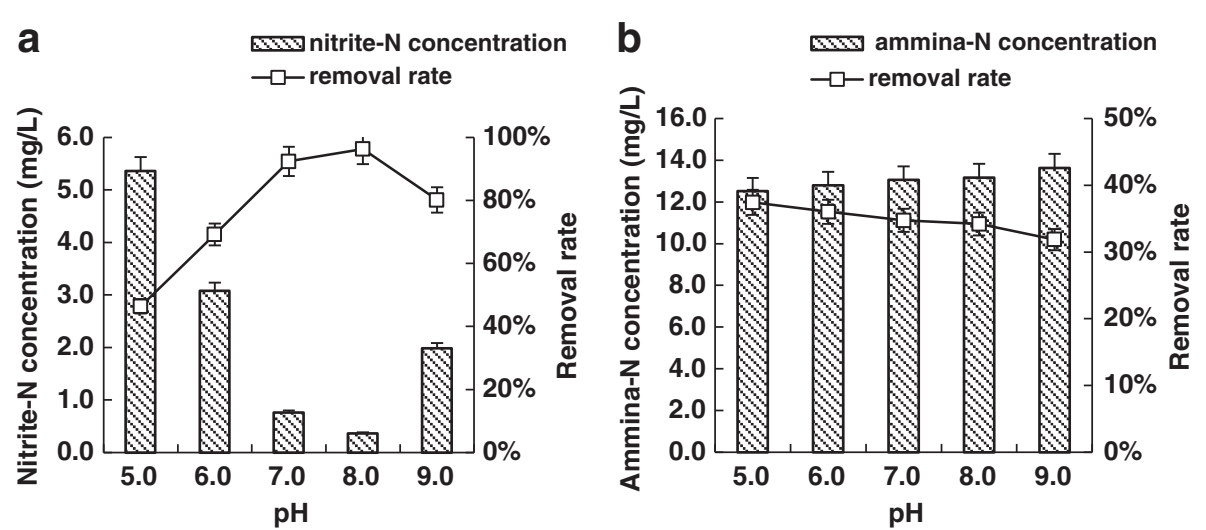

Figure 4 Effects of $\mathrm{pH}$ on the removal rates of nitrite-N and ammonia-N. a) Effects of $\mathrm{pH}$ on nitrite-N removal rate; $\mathbf{b}$ ) Effects of pH on the ammonia-N removal rate. 
and $21.6 \%$ of the total nitrite-N) was eliminated for an initial nitrite- $\mathrm{N}$ concentration of $40 \mathrm{mg} \mathrm{l}^{-1}$ and $80 \mathrm{mg} \mathrm{l}^{-1}$, respectively. The removal rate, however, did not significantly elevated with the time (the residue nitrite- $\mathrm{N}$ even increased a little for $80 \mathrm{mg} \mathrm{l}^{-1}$ ), suggesting that the maximum removal concentration of nitrite- $\mathrm{N}$ might be around $20 \mathrm{mg} \mathrm{l}^{-1}$.

With high initial ammonia- $\mathrm{N}$ concentrations $\left(20 \mathrm{mg} \mathrm{l}^{-1}\right.$ and $40 \mathrm{mg} \mathrm{l}^{-1}$ ), the removal rates of ammonia- $\mathrm{N}$ were significant, and maximum removal rates of $59.8 \%$ and $79.8 \%$ were reached at $48 \mathrm{~h}$ (Figure 2b). As for low initial ammonia- $\mathrm{N}$ concentrations $\left(10 \mathrm{mg} \mathrm{l}^{-1}\right.$ and $\left.20 \mathrm{mg} \mathrm{l}^{-1}\right)$, the removal efficiencies of ammonia-N were not efficient. During the time course, the residue ammonia- $\mathrm{N}$ levels fluctuated around $10 \mathrm{mg} \mathrm{l}^{-1}$, suggesting that $B$. amyloliquefaciens $\mathrm{HN}$ could not only utilize ammonia- $\mathrm{N}$ but also produce it.

\section{Effects of temperature on the nitrite- $\mathrm{N}$ and ammonia- $\mathrm{N}$ removal abilities of $\mathrm{B}$. amyloliquefaciens $\mathrm{HN}$}

The nitrite- $\mathrm{N}$ removal rates of $B$. amyloliquefaciens $\mathrm{HN}$ at $25^{\circ} \mathrm{C}, 30^{\circ} \mathrm{C}$ and $35^{\circ} \mathrm{C}$ all reached $99 \%$ (Figure 3a), suggesting temperature (over the experimental range) did not affect the removal of nitrite-N. The ammonia-N removal rates at $25^{\circ} \mathrm{C}, 30^{\circ} \mathrm{C}$ and $35^{\circ} \mathrm{C}$ were $29 \%, 37.5 \%$ and $39.4 \%$ respectively (Figure $3 \mathrm{~b}$ ), suggesting higher temperature might be preferable for effective removal of ammonia-N by B. amyloliquefaciens $\mathrm{HN}$.

\section{Effects of $\mathrm{pH}$ on the nitrite- $\mathrm{N}$ and ammonia- $\mathrm{N}$ removal abilities of $B$. amyloliquefaciens $\mathrm{HN}$}

Figure $4 \mathrm{a}$ showed that $\mathrm{pH}$ remarkably influenced the removal of nitrite-N by B. amyloliquefaciens HN. Nitrite-N removal rates increased significantly with increased $\mathrm{pH}$ value. A maximum removal rate of $96 \%$ could be reached at $\mathrm{pH}$ 8.0. Further increase of $\mathrm{pH}$ reduced the removal rate. Ammonia-N removal rates from $\mathrm{pH} 5.0 \sim 9.0$ were between $32 \sim 38 \%$, suggesting $\mathrm{pH}$ had no significant effects on the removal of ammonia-N (Figure 4b).

\section{Discussion}

In this work, we investigated the potential of using $B$. amyloliquefaciens in the remediation of aquaculture water. Particularly, its remediation characteristics regarding nitrite and ammonia removal were evaluated. The accumulation of nitrite and ammonia is highly toxic to aquatic fauna. $0.1 \sim 10 \mathrm{mg} \mathrm{l}^{-1}$ of nitrite can cause $50 \%$ mortality (LC 50) of a number of fish and shrimp (Philips et al. 2002). Ammonia-N can be toxic to commercially cultured fish at concentrations above $1.5 \mathrm{mg} \mathrm{l}^{-1}$ (Crab et al. 2007).

Bacillus species are important candidates for developing commercial biological agents for nitrogen removal and water quality enhancement (Hong et al. 2005). Previously, a few studies reported that some strains of $B$. subtilis (Chen and $\mathrm{Hu}$ 2011; Meng et al. 2009), B. lichenformis (Meng et al. 2009) and B. cereus (Lalloo et al. 2007) exhibited strong nitrite removal ability. Physiological studies on Bacillus spp. also showed that Bacillus spp. could utilize nitrate and nitrite as alternative electron acceptors and nitrogen sources (Nakano et al. 1998; Hoffmann et al. 1998).

This study showed that an B. amyloliquefaciens strain, isolated from the activated sludge, was also a very efficient nitrite- $\mathrm{N}$ cleaner, which was able to completely remove $10 \mathrm{mg} \mathrm{l}^{-1}$ of nitrite-N present in the simulated aquaculture water within $24 \mathrm{~h}$. In the past, B. amyloliquefaciens were applied in enzyme production (Wei et al. 2011), plant disease control (Alvindia and Natsuaki 2009; Arrebola et al. 2010) and food preservation (Wang et al. 2006). This is the first study on its potential application in improving water quality. It suggested that $B$. amyloliquefaciens might be an important alternative Bacillus species for nitrite removal.

The ammonia-N removal ability of $B$. amyloliquefaciens was not satisfying, because when the ammonia- $\mathrm{N}$ concentration was below $20 \mathrm{mg} \mathrm{l}^{-1}$, the removal rate was at best $39.4 \%$ and the ammonia- $\mathrm{N}$ concentration cannot be reduced below $10 \mathrm{mg} \mathrm{l}^{-1}$. Past literature seems to suggest that Bacillus species are not very efficient in ammonia removal, and no ammonia removal efficiency of a single Bacillus strain has been reported to exceed 90\%. Therefore, to create a microbal agent which can simultaneously eliminate nitrite and ammonia, B. amyloliquefaciens $\mathrm{NH}$ can be formulated with efficient ammonia reducing bacteria, such as nitrifying bacteria (Meng et al. 2009).

\section{Competing interests}

The authors declare that they have no competing interests.

\section{Authors' contributions}

Conceived and designed the experiments: FX, ZL. Performed the experiments: FX,FZ,KZ,YZ. Analyzed the data: FX, TZ, ZL. Wrote the paper: FX, $Z T, Z L$. All authors read and approved the final manuscript.

\section{Acknowledgement \\ This work is supported by Key Projects in Science and Technology Support Program of Tianjin, China (10ZCZDSY06100), Major Projects in Science and Technology Support Program of Tianjin, China (11ZCKFNC00500) and the Knowledge Innovation Program of the Chinese Academy of Sciences (KSCX2-EW-G-15-03).}

\section{Author details}

'Tianjin Institute of Industrial Biotechnology, Chinese Academy of Sciences, 32XiQiDao, Tianjin Airport Economic Park, Tianjin 300308, People's Republic of China. ${ }^{2}$ Tianjin Research Center of Agricultural Biotechnology, Tianjin 300192, People's Republic of China. ${ }^{3}$ Institute of Microbiology, Chinese Academy of Sciences, Beijing 100101, People's Republic of China.

Received: 29 November 2012 Accepted: 27 February 2013 Published: 20 March 2013

\section{References}

Alvindia DG, Natsuaki KT (2009) Biocontrol activities of Bacillus amyloliquefaciens DGA14 isolated from banana fruit surface against banana crown rot-causing pathogens. Crop Prot 28(3):236-242

Apha A WPCF (2005) Standard methods for the examination of water and wastewater. Public Health Association, Washington, DC 


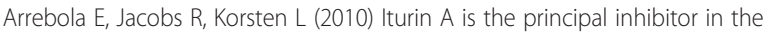
biocontrol activity of Bacillus amyloliquefaciens PPCB004 against postharvest fungal pathogens. J Appl Microbiol 108(2):386-395

Cataldo D, Haroon M, Schrader L, Youngs V (1975) Rapid colorimetric determination of nitrate in plant-tissue by nitration of salicylic-acid. 1(6):71-80

Chen GK, Chen G (2005) Effect of synthetic wastewater on some physicochemical properties of soil in Avicennia marina simulated wetland system. Mar Environ Sci 24(2):26-28

Chen S, Hu Y (2011) Use of Bacillus subtilis in purification of slightly-polluted water. Acta Scienctiae Circumstantiae 31(8):1594-1601

Crab R, Avnimelech Y, Defoirdt T, Bossier P, Verstraete W (2007) Nitrogen removal techniques in aquaculture for a sustainable production. Aquaculture 270(1-4):1-14

De-Bashan LE, Moreno M, Hernandez JP (2002) Removal of ammonium and phosphorus ions from synthetic wastewater by the microalgae Chlorella vulgaris coimmobilizedin alginate beads with the microalgae growth promoting bacterium Azospirilum brasilense. Water Res 36(12):2941-2948

Hoffmann T, Frankenberg N, Marino M, Jahn D (1998) Ammonification in Bacillus subtilis utilizing dissimilatory nitrite reductase is dependent on resDE. J Bacteriol 180(1):186-189

Hong HA, Duc H, Cutting SM (2005) The use of bacterial spore formers as probiotics. FEMS Microbiol Rev 29(4):813-835

Lalloo R, Ramchuran S, Ramduth D, Görgens J, Gardiner N (2007) Isolation and selection of Bacillus spp. as potential biological agents for enhancement of water quality in culture of ornamental fish. J Appl Microbiol 103(5):1471-1479

Meng R, He LS, Xi BD, Hu X, Li YY (2009) Experimental study on purifying aquaculture wastewater between Bacillus and nitrifying bacteria. Environ Sci Technol 32(11):28-31

Mohapatra S, Chakraborty T, Kumar V, Deboeck G, Mohanta KN (2012) Aquaculture and stress management: a review of probiotic intervention. $J$ Anim Physiol Anim Nutr:1-26. doi:10.1111/j.1439-0396.2012.01301.x

Nakano MM, Hoffmann T, Zhu Y, Jahn D (1998) Nitrogen and oxygen regulation of Bacillus subtilis nasDEF encoding NADH-dependent nitrite reductase by TnrA and ResDE. J Bacteriol 180(20):5344-5350

Ninawe AS, Selvin J (2009) Probiotics in shrimp aquaculture: avenues and challenges. Crit Rev Microbiol 35(1):43-66

Philips S, Laanbroek HJ, Verstraete W (2002) Origin, causes and effects of increased nitrite concentrations in aquatic environments. 1(2):115-141

Verschuere L, Rombaut G, Sorgeloos P, Verstraete W (2000) Probiotic bacteria as biological control agents in aquaculture. Microbiol Mol Biol Rev 64(4):655-671

Wang J, Quan C, Xu H, Fan S (2006) Antifungal characterization of Bacillus amyloliquefaciens Q-12. Food Ferment Ind 32(6):47-50

Wei X, Luo M, Xu L, Zhang Y, Lin X, Kong P, Liu H (2011) Production of fibrinolytic enzyme from Bacillus amyloliquefaciens by fermentation of chickpeas, with the evaluation of the anticoagulant and antioxidant properties of chickpeas. J Agric Food Chem 59(8):3957-3963

doi:10.1186/2193-1801-2-119

Cite this article as: Xie et al.: Using Bacillus amyloliquefaciens for remediation of aquaculture water. SpringerPlus 2013 2:119.

\section{Submit your manuscript to a SpringerOpen ${ }^{\circ}$ journal and benefit from:}

- Convenient online submission

- Rigorous peer review

- Immediate publication on acceptance

- Open access: articles freely available online

- High visibility within the field

- Retaining the copyright to your article

Submit your next manuscript at $>$ springeropen.com 